\title{
FinTech Waqaf: Solusi Permodalan Perusahaan Startup Wirausaha Muda
}

\author{
Muhamad Nafik Hadi Ryandono \\ Fakultas Ekonomi dan Bisnis Universitas Airlangga \\ muhammadnafik@feb.unair.ac.id
}

\section{ABSTRAK}

Wakaf uang di Indonesia memiliki potensi yang sangat besar dan mudah dikelola dibandingkan dengan wakaf aset tidak bergerak. Wakaf uang juga lebih mudah digunakan sebagai sumber permodalan baik untuk perusahan yang sudah stabil maupun perusahaan baru (startup). Walaupun faktanya potensi yang besar tersebut belum terorganisir dan termanfaatkan dengan maksimal oleh lembaga pengelola wakaf. Masalah lain dalam perwakafan uang adalah sulitnya mengintegrasikan sistem funding, financing, mauquf alaih, dan pendistribusian keuntungannya. Pada era sekarang perwakafan di Indonesia juga belum melalui proses digitalisasi dan belum menggunakan sistem Financial Technology (FinTech) sehingga kurang ekonomis dan efisien. Manfaat penelitian yang diharapkan adalah wakaf dapat menjadi solusi permasalahan permodalan yang selama ini dihadapi perusahaan startup. Selain itu juga mendorong nadzir mau terlibat dalam menumbuhkan dan mengembangkan kewirausahaan bagi para pemuda yang dapat dimulai dengan mendirikan perusahaan startup. Pendekatan penelitian ini adalah kualitatif deskriptif. Data yang diambil adalah data primer dengan focus group discussion dan wawancara sebagai teknik pengumpulan data. Objek penelitian terdiri dari 30 startup milik pemuda di Surabaya. Hasil dari penelitian ini adalah wakaf uang dapat dijadikan sebagai alternatif solusi yang ekonomis dalam permasalahan permodalan bagi perusahaan startup yang unbankable milik para pemuda. Sistem Sharia Financial Technology (SFT) merupakan sistem yang mampu mengintegrasikan nadzir dengan Lembaga Keuangan Syariah Penerima Wakaf Uang (LKSPWU), funding, financing, mauquf alaih, investor perusahaan startup, Lembaga Penjaminan Pembiayaan Islam (LPPI), dan Bank Islam.

KATA KUNCI Financial Technology | Permodalan | Startup | Wakaf | Perusahaan.

\section{PENDAHULUAN}

Komposisi pemuda Indonesia berdasarkan hasil Susenas Badan Pusat Statistik (BPS) adalah seperti tertera pada Tabel 1.

Tabel 1

Persentase Pemuda Indonesia 2013-2017

\begin{tabular}{|c|c|c|}
\hline No. & Tahun & Persentase Pemuda Indonesia (\%) \\
\hline 1 & 2013 & 24,79 \\
\hline 2 & 2014 & 24,53 \\
\hline 3 & 2015 & 24,20 \\
\hline 4 & 2016 & 24,07 \\
\hline 5 & 2017 & 24,27 \\
\hline
\end{tabular}

Sumber: BPS, Susenas 2013-2017
Jumlah pemuda yang besar dalam komposisi penduduk Indonesia sebagaimana tertera dalam Tabel 1 di atas, tentu membutuhkan perlakukan khusus agar menjadi generasi penerus yang handal di masa mendatang. Perhatian khusus tersebut dibutuhkan karena pemuda merupakan individu yang sedang mencari jati diri dan identitas untuk menjadi orang dewasa. Sutopo dan Meiji (2014) mengungkapkan bahwa, menurut perspektif psikologi perkembangan, pemuda dianggap berada dalam masa storm and struggle terutama pada faktor internal, pemuda mencoba bereksperimen dengan identitas orang dewasa. Masa transisi krusial lainya adalah transisi dari 
dunia pendidikan ke dunia kerja. Dalam konteks Indonesia, ancaman terbesar adalah dari hegemoni rezim neoliberal dimana pemuda harus menghadapi hambatan struktural yang semakin besar dan berlapis dalam transisi dari dunia pendidikan ke dunia kerja (Sutopo dan Meiji 2014).

Fakta dunia kerja menunjukkan bahwa pencari kerja atau pengangguran terbuka terbesar di Indonesia adalah pemuda. Hal ini dapat dilihat pada data di Tabel 2. Gambaran yang dapat diambil dari Tabel 2 adalah mayoritas pemuda Indonesia lebih memilih menjadi pekerja daripada menciptakan lapangan pekerjaan dengan menjadi pengusaha. Mengapa demikian? Karena dengan bekerja akan menjamin pendapatan yang stabil dan bersifat tetap secara periodik. Namun, jika menjadi pengusaha akan memiliki pendapatan yang tidak stabil sehingga masa depan tidak terjamin. Pola pikir yang demikian senada dengan pendapat Sutopo dan Meiji (2014), aspirasi pemuda masih mensyaratkan bahwa menempuh pendidikan tinggi, mendapatkan pekerjaan yang menjanjikan gaji teratur, dan membina rumah tangga adalah aspirasi yang ideal mengenai masa depan.

\section{Tabel 2}

Tingkat Pengangguran Terbuka Berdasarkan Kelompok Umur

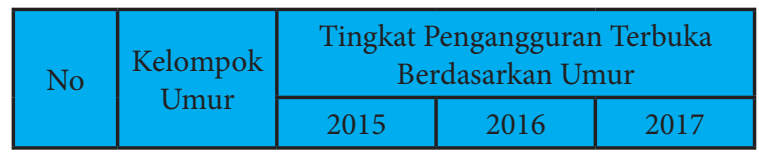

\begin{tabular}{|c|c|c|c|c|}
\hline 1 & $15-19$ & 17.71 & 28.09 & 27.54 \\
\hline 2 & $20-24$ & 12.86 & 15.8 & 16.62 \\
\hline 3 & $25-29$ & 10.65 & 7.08 & 6.76 \\
\hline 4 & $30-34$ & 8.86 & 3.63 & 3.4 \\
\hline \multicolumn{2}{|c|}{ Total } & 50.08 & 54.6 & 54.32 \\
\hline 5 & $35-39$ & 7.86 & 2.21 & 2.45 \\
\hline 6 & $40-44$ & 7.59 & 2.05 & 1.86 \\
\hline 7 & $45-49$ & 6.97 & 1.35 & 1.51 \\
\hline 8 & $50-54$ & 5.93 & 1.66 & 1.54 \\
\hline 9 & $55-59$ & 6.05 & 1.55 & 1.73 \\
\hline 10 & $>60$ & 4.74 & 1.51 & 1.52 \\
\hline
\end{tabular}

Sumber: BPS 2015-2017

Apabila mayoritas pemuda Indonesia lebih memilih menjadi pekerja daripada pengusaha maka negara Indonesia akan sulit mandiri secara ekonomi.
Banyak pendapat mengatakan bahwa apabila suatu negara mau mandiri maka $4 \%$ penduduknya harus berprofesi sebagai pengusaha. Salah satunya dikemukakan oleh Syarkawi (2018), Perekonomian suatu negara akan mandiri dan mampu tumbuh berkembang dengan optimum apabila negara tersebut memiliki minimal $4 \%$ pengusaha dari jumlah penduduknya. Indonesia sekarang baru memiliki 1,65-1,8\% atau sebesar 4,6 Juta pengusaha. Padahal jumlah pengusaha Indonesia idealnya (4\%) adalah sebesar 10,6 Juta, berarti masih kurang sekitar 6 juta pengusaha baru. Dengan demikian, para pemuda pencari kerja tersebut harus disadarkan dan diarahkan menjadi pengusaha. Hal ini diharapkan agar 4\% jumlah penduduk Indonesia menjadi pengusaha segera tercapai. Walaupun ini bukan merupakan hal yang mudah, tetapi harus segera dimulai. Mendorong lahirnya pengusaha baru dibutuhkan proses bagaimana menumbuhkan jiwa wirausaha bagi pemuda Indonesia sejak di bangku pendidikan.

Wahana yang banyak digunakan untuk melahirkan pengusaha baru baik di dunia pendidikan maupun non-pendidikan pada umumnya dilakukan oleh sebuah lembaga yang berfungsi menginkubasi usaha-usaha baru. Lembaga yang demikian lebih dikenal dengan sebutan inkubator bisnis. Para inkubator bisnis ini melakukan inkubasi terhadap rintisan usaha atau bisnis baru. Peserta inkubasi ini disebut sebagai tenant. Peserta ini biasanya ditujukan pada para pengusaha yang memiliki perusahaan startup. Hal ini dikarenakan perusahaan startup merupakan perusahaan yang baru lahir sehingga membutuhkan pelatihan dalam sebuah inkubator bisnis. Tujuannya agar tumbuh dan berkembang normal menjadi perusahaan yang sustainable dalam menghadapi permasalahan bisnis baik secara mikro maupun makro.

Pada tahun 2016 usaha startup di Indonesia mencapai angka 2000 perusahaan (Nasscom 2016). Hubeis dan Lupiyoadi (2004) menyatakan bahwa hampir $80 \%$ startup di Indonesia gagal pada tahun pertama. Hal tersebut senada dengan pernyataan Wirasasmitra (1998) bahwa tingkat kegagalan usaha kecil di Indonesia mencapai 78\%. Mayoritas perusahaan startup pada umumnya adalah Usaha Mikro Kecil dan Menengah (UMKM). Terdapat berbagai penyebab tingginya tingkat kegagalan bisnis startup. 
Pada penelitian Colis (2001) didapatkan bahwa faktor utama yang mempengaruhi kegagalan startup adalah kekurangan modal sehingga tidak dapat menghasilkan turnover bagi perkembangan usaha.

Pada realitasnya banyak perusahaan startup tidak mampu bertahan bahkan layu dan mati sebelum berkembang. Hal ini diakibatkan pada ketidakmampuannya dalam memecahkan permasalahan yang dihadapi khususnya permodalan. Untuk menghadapi persoalan ini, diperlukan sebuah mitigasi sebagai langkah awal yang efektif dalam menemukan solusi. Berdasarkan hasil mitigasi tersebut akan diharapkan dapat menghasilkan solusi alternatif dalam proses pemecahan masalah serta langkah-langkah yang spesifik, terukur, akurat, dapat dipercaya, dan tepat waktu. Pada penelitian ini untuk menemukan permasalahan yang dihadapi oleh para startup maka dilakukan penelitian pendahuluan dengan melakukan Focus Group Discussion (FGD) dengan para startup di Surabaya.

Hasil penelitian pendahuluan terhadap 30 pengusaha startup ini teridentifikasi bahwa pada umumnya menghadapi 8 (delapan) permasalahan yang mayoritas sama. Delapan permasalahan tersebut adalah: 1) Berbisnis bukan menjadi cita-cita atau hanya bersifat coba-caba dan sambil mengisi waktu sebelum mendapat pekerjaan sehingga mereka tidak mempersiapkan diri sejak awal, 2) Pemasaran dan pasar baik bahan baku maupun produk, 3) Permodalan, 4) Perkembangan teknologi, 5) Administrasi bisnis dan akuntansi keuangan, 6) Jejaring, 7) Legalitas (kelembagaan badan usaha, Perlindungan hukum (paten, merk, sertifikasi produk, sertifikasi halal dan lainnya), 8) Orientasi pasar terfokus pada area domestik dan lokal.

Pada saat dilakukan pendalaman dari delapan permasalahan tersebut menghasilkan permasalahan yang lebih spesifik yaitu modal. Masalah permodalan menjadi masalah utama bagi perusahaan startup karena perusahaan yang dibentuk merupakan usaha baru sehinga secara kelembagaan maupun administrasi bisnis belum stabil. Sehingga hal ini berdampak pada sulitnya akses keuangan karena dinilai belum bankable. Kondisi yang demikian sebenarnya wajar karena perusahaan startup adalah perusahaan yang masih dalam proses mencari model bisnis yang kontinu dan terukur agar mampu mandiri. Pada FGD tersebut selanjutnya terfokus pada bagaimana mencari solusi permasalahan permodalan tersebut.

Pada saat diskusi lebih lanjut muncul pemikiran yaitu bagaimana permodalan perusahaan startup dengan memanfaatkan Financial Technology (FinTech) yang sedang booming untuk crowdfunding berbasis wakaf. Argumennya, wakaf adalah menyerahkan aset baik berwujud uang maupun nonuang untuk kepentingan dan keuntungan masyarakat umum. Namun, pokok aset wakaf tidak boleh berkurang dan aset tersebut menjadi milik umum yang dikelola oleh lembaga wakaf (nadzir). Pokok aset wakaf agar tidak berkurang harus diproduktifkan, salah satunya dengan memanfaatkannya untuk memperkuat permodalan perusahaan startup. Hal ini relevan dengan pendapat Hidayat (2018) bahwa wakaf tidak bisa dilepaskan dari instrumen pembangunan ekonomi bangsa Indonesia. Hal ini dapat dilihat dari potensi aset wakaf di Indonesia yang mencapai Rp. 200 triliun dan potensi wakaf uang mencapai $\mathrm{Rp}$. 188 triliun pertahun. Jadi, wakaf punya kemampuan untuk berkontribusi pada pembangunan bangsa ini, baik aspek infrastruktur, pendidikan, kesehatan, maupun aspek sosial, dan keagamaan lainnya. Walaupun faktanya tidak mudah untuk memobilisasi potensi wakaf uang yang sangat besar tersebut, karena fakta di lapangan banyak faktor yang memengaruhinya. Menurut Fauzia (2016), mekanisme pelaksanaan zakat terkait erat dengan fenomena sosial, ekonomi, dan politik umat Islam.

Potensi yang besar dari wakaf tersebut diharapkan mampu menjadi altenatif solusi atas masalah permodalan pada perusahaan startup. Dimana yang selama ini terjadi bagaikan lingkaran setan yang sulit diputus dan dipecahkan. Apabila perusahaan startup itu berkembang dengan dukungan permodalan dari wakaf maka akan banyak memberikan nilai tambah bagi perekonomian, di sinilah keuntungan yang diberikan dari wakaf. Lembaga wakaf juga bisa menjadi pemegang saham pada perusahaan-perusahaan startup tersebut dengan demikian aset wakaf akan terus berkembang dan tumbuh dalam menciptakan nilai tambah dan keuntungan secara berkelanjutan sekaligus berkesinambungan.

Berdasarkan uraian di atas dan hasil Focus 
Group Discussion (FGD) tersebut maka penelitian ini mengambil rumusan masalah; bagaimana model FinTech wakaf sebagai solusi permodalan perusahaan startup wirausaha muda? Tujuan penelitiannya adalah membangun model FinTech wakaf sebagai solusi permodalan perusahaan startup wirausaha muda. Manfaat penelitian yang diharapkan adalah wakaf dapat menjadi solusi permasalahan permodalan. Dimana permasalahan tersebut sering dihadapi oleh perusahaan startup yang pada umumnya belum bankable. Manfaat lainnya yaitu hasil penelitian ini memberikan spirit dan mendorong lembaga pengelola Zakat Infaq Shadaqah dan Wakaf (Laziswaf) khusus lembaga pengelola wakaf (nadzir) terlibat dalam menumbuhkan dan mengembangkan kewirausahaan bagi para pemuda dimulai dengan mendirikan perusahaan startup.

\section{KERANGKA TEORI}

\section{Perusahaan Rintisan (Startup)}

Diskusi tentang perusahaan pasti tidak bisa dilepaskan dari pembahasan tentang kewirausahaan. Kewirausahaan sendiri merupakan semangat, perilaku, dan kemampuan untuk memberikan tanggapan positif terhadap peluang memperoleh keuntungan untuk diri sendiri dan/atau pelayanan lebih baik, serta menciptakan dan menyediakan produk yang lebih bermanfaat dan menerapkan cara kerja yang efisien melalui keberanian mengambil risiko, kreativitas dan inovasi serta kemampuan manajemen (Hasanah 2015). Seseorang yang mengimplementasikan kewirausahaan dengan cara mendirikan badan usaha atau bisnis disebut pengusaha. Perusahaan pemula atau perusahaan rintisan atau perusahaan yang baru didirikan dikenal dengan istilah perusahaan startup. Blank (2010), mendefinisikan startup bisnis sebagai organisasi yang dibentuk untuk mencari model bisnis yang repeatabe dan scalable.

Secara umum perusahan startup memiliki beberapa karakter, yaitu; 1) Perusahaan berumur kurang dari 3 tahun, 2) Karyawan yang dimiliki kurang dari 20 orang, 3) Omset penjualan pertahun kurang dari $\$ 100.000,00,4)$ Perusahaan dalam tahap perkembangan, 5) Mayoritas bergerak dalam bidang teknologi, 6) Produknya pada umumnya ber- basis aplikasi dalam model digital, dan 7) Umumnya beroperasi dan bergerak berbasis website dan online, serta 8) Pelakunya mayoritas pemuda.

Berdasarkan penelitian Damodaran (2009) menjelaskan bahwa terdapat faktor-faktor yang menjadi masalah pada startup dan harus ditangani oleh program yang sesuai untuk menumbuhkan wirausahawan muda. Menurut Schoof (2016:42) bahwa beberapa permasalahan pendanaan tersebut disebabkan oleh faktor-faktor berikut, yaitu: a) Kurangnya simpanan dan sumber daya pribadi; b) Kurangnya sekuritas dan kredibilitas (untuk pembiayaan utang) c) Kurangnya pengalaman bisnis dan keterampilan (untuk pembiayaan utang); d) Metodologi dan peraturan pemberian kredit yang ketat; e) Prosedur dokumentasi yang rumit; f) Masa tunggu yang panjang (waktu yang dibutuhkan untuk memutuskan aplikasi untuk pendanaan) g) Kurangnya pengetahuan, pemahaman, kesadaran akan kemungkinan pendanaan awal; h) Karakteristik dan industri yang tidak menguntungkan; i) Status hukum/bentuk perusahaan; j) Kurangnya (berhasil) pinjaman mikro/pembiayaan dan pendanaan pembibitan. Faktor tersebut menjadikan perusahaan startup sulit mengakses modal dari perbankan karena tidak bankable. Dengan demikian diperlukan alternatif solusi yang ekonomis dan sesuai dengan kondisi riil perusahaan startup.

2. Teknologi Finansial Wakaf sebagai Sumber Permodalan pada perusahaan Startup

Menurut National Digital Research Centre (NDRC), Financial Technology adalah istilah yang biasa digunakan untuk menyebut suatu inovasi di bidang jasa finansial. FinTech sendiri berasal dari kata financial dan technology yang mengacu pada inovasi finansial dengan sentuhan teknologi modern. Konsep financial technology mengadaptasi perkembangan teknologi yang dipadukan dengan bidang finansial pada lembaga keuangan perbankan, sehingga diharapkan dapat memfasilitasi proses transaksi keuangan yang lebih praktis, aman, serta modern. Layanan keuangan berbasis digital yang saat ini telah berkembang di Indonesia, yaitu payment channel system, digital banking, online digital insurance, Peer to Peer (P2P) Lending, serta crowdfunding (Siregar 2016). 
Romanova dan Kudinska (2016), mendefinisikan FinTech sebagai salah satu bisnis berbasis software dan teknologi modern yang menyediakan jasa keuangan. Perusahaan FinTech pada umumnya adalah perusahaan yang memberikan layanan dan solusi keuangan kepada pelanggan seperti pembayaran mobile, transfer uang, pinjaman, penggalangan dana, dan bahkan manajemen aset. Berdasarkan analisis pengembangan FinTech dan kekhasan bisnis ini, teridentifikasi keunggulan komparatif dari FinTech, yaitu: layanan keuangan yang sangat terstandar dan berbiaya rendah; berbasis internet dan karena itu kurang terkonsentrasi secara geografis; mengubah perilaku konsumen; regulasi layanan keuangan yang lebih rendah risiko, relatif lebih rendah dari layanan/ produk keuangan misalnya, peminjam gagal bayar risiko, dan risiko jatuh tempo (Romanova dan Kudinska 2016).

FinTech diakui sebagai satu inovasi paling penting dalam industri keuangan dan berkembang dengan cepat, didorong oleh pemerataaan ekonomi, regulasi yang menguntungkan, dan teknologi informasi. Menurut Lee dan Shin (2018), FinTech menjanjikan ekosistem baru bagi industri keuangan dengan biaya rendah, meningkatkan kualitas layanan keuangan, dan menciptakan lanskap keuangan yang lebih beragam dan stabil. Lima elemen ekosistem FinTech, antara lain: 1) FinTech Startup (pembayaran, pinjaman, crowdfunding, pasar modal, dan perusahaan asuransi; 2) Technology developers (misalnya, analisis big data, cloud computing, cryptocurrency, dan developers media sosial; 3) Pemerintah (misalnya, regulator keuangan dan badan legislatif); 4) Pelanggan keuangan (misalnya, individu dan organisasi); serta 5) Lembaga keuangan tradisional (misalnya, bank tradisional, perusahaan asuransi, pialang saham, dan modal ventura).

Teknologi finansial (financial Technology, FinTech) menurut Peraturan Bank Indonesia nomor 19/12/PBI/2017 tentang Penyelenggaraan Teknologi Finansial dapat menyelenggaraan aktivitas keuangan yang berupa;
a. Sistem pembayaran
b. Pendukung pasar

c. Manajemen Investasi dan Manajemen resiko

d. Pimjaman, pembiayaan dan penyediaan modal e. Jasa finansial lainnya.

Adapun tantangan pasar FinTech Syariah menurut Telkom Indonesia (2017) adalah: (1) Kesadaran dan pengetahuan masyarakat tentang keuangan syariah, khususnya FinTech Syariah yang masih kurang; (2) Pertumbuhan ekonomi syariah lambat dan pangsa pasarnya masih kecil; (3) SDM berkualitas di bidang ekonomi syariah masih kurang; (4) Sinergi antara sesama lembaga keuangan syariah dengan lembaga-lembaga sosial yang bergerak di bidang ekonomi umat, seperti dengan lembaga zakat dan wakaf masih lemah.

Wakaf adalah alat filantropi Islam sejak awal kedatangan Islam. Wakaf telah terbukti menjadi instrumen jaminan sosial, tidak hanya untuk membantu kebutuhan dasar tetapi juga memainkan bagian dalam pemberdayaan yang lebih produktif di semua sektor seperti pendidikan, sosial, ekonomi, dan budaya. Selain aset yang tidak bergerak dari wakaf, ada juga wakaf tunai yang lebih produktif digunakan. Wakaf tunai yang sangat potensial namun tidak populer menyebabkan peran wakaf belum optimal menjadi sebuah instrumen kesejahteraan masyarakat. Indonesia dengan jumlah muslim terbesar di dunia, seharusnya menjadi landasan untuk mengoptimalkan wakaf (Sifa dan Nurhalimatus 2016). Pendapat lebih lanjut dari Sifa dan Nurhalimatus (2016), manajemen dan pengembangan wakaf tunai di Indonesia dapat dicapai melalui investasi pada produk-produk lembaga keuangan syariah dan atau instrumen keuangan syariah. Wakaf tunai memberikan banyak peluang besar, tidak hanya dialokasikan untuk pembangunan infrastruktur tetapi juga memberikan peluang bagi pengembangan orang lain, ada untuk pendidikan, kesehatan, sanitasi, dan layanan sosial. Pengumpulan, pengelolaan dan pendistribusian manfaat agar lebih efisien dan terkontrol dengan baik maka harus memanfaatkan kemajuan teknologi informasi atau e-waqf. Ada beberapa keuntungan sistem e-waqf ini antara lain;

\begin{tabular}{l|l} 
a. & $\begin{array}{l}\text { Mobilisasi dana wakaf yang lebih mudah dari } \\
\text { masyarakat. }\end{array}$ \\
\hline
\end{tabular} 
b. Wakaf uang lebih fleksibel dan menjadi pendorong bagi aset wakaf yang tak bergerak, agar lebih produktif.

c. Transaksi wakaf berbasis aplikasi merupakan formulir aplikasi yang dapat dimiliki oleh pengguna smartphone di dunia.

d. Ada pemetaan distribusi kekayaan wakaf dan tidak terakumulasi di daerah setempat. Ini juga bertujuan untuk mendistribusikan kekayaan dan menghilangkan kesenjangan.

e. Transparansi kekayaan wakaf, sehingga dapat menambah kepercayaan muwaqif.

Wakaf uang dapat digunakan sebagai sumber permodalan bagi dunia usaha khususnya bagi perusahaan yang dengan tujuan utamanya untuk pemberdayaan usaha masyarakat yang pada umunya UMKM dan perusahaan startup.

\section{METODE PENELITIAN}

Penelitian ini menggunakan pendekatan kualitatif yang bersifat penelitian diskriptif. Penelitian ini untuk mendeskripsikan Sharia Financial Technology (SFT) sebagai sarana mengintegrasikan solusi permodalan perusahaan startup yang dikembangkan oleh pemuda dengan berbasis wakaf. Pengumpulan datanya dengan cara wawancara dan FGD dengan para perusahaan startup dan pengelola wakaf (nadzir). Perusahaan startup yang dijadikan objek adalah 30 perusahaan yang berdomisili di Surabaya dan difokuskan pada pemuda sebagai para pelakunya.

\section{TEMUAN DAN ANALISIS}

Perusahaan startup tentunya banyak menghadapi permasalahan. Kondisi inilah yang membuat startup bisnis membutuhkan pendampingan agar mampu menyelesaikan permasalahannya sehingga menjadi sebuah bisnis yang sukses dan berkelanjutan. Mentoring, jaringan pendukung, layanan Business Development Servive (BDS), asosiasi dan forum bisnis, dan inkubasi dapat menjadi kunci kesuksesan untuk membantu perusahaan startup yang merintis bisnis mulai dari skala usaha kecil dan menengah sehingga dapat menjadi mandiri dan naik kelas. Pada kondisi demikian lembaga inkubasi bisnis menjadi penting untuk tidak hanya membimbing startup tetapi juga untuk mengawal permodalannya agar dapat sustainable.

Permodalan yang digunakan untuk penguatan modal bagi para bisnis startup pada kenyataannya secara mayoritas belum bankable. Sehingga diperlukan model permodalan yang bersifat filantropi baik berwujud hibah maupun produktif serta pembiayaan dengan syarat yang memungkinkan sesuai dengan karakteristik bisnis startup. Permodalan lainnya dapat dengan skema modal bergulir dengan agunan yang dijamin oleh pihak lain baik lembaga penjaminan pemerintah maupun lembaga pejaminan yang berkolaborasi dengan lembaga filantropi. Dasar kelayakan yang digunakan untuk memberikan penguatan modal adalah rencana bisnis, komitmen dan tanggung jawab, partisipasi ekuitas yang wajar, dan kemampuan untuk membayar kembali penguatan modal yang diterima baik secara bergulir maupun pokok kembali pokok dan atau berskema imbal hasil berbasis pendapatan. Apabila imbal hasil berbasiskan pada modal yang diterima akan menjadi beban. Hal ini mengingat bisnis masih pada tahap startup yang tentunya masih pada masa pertumbuhan dan umumnya pada siklus ini profit masih rendah karena belum efisien dalam operasional dan masih dalam penetrasi dan membangun pasar produknya.

Sumber permodalan yang ekonomis bagi startup sesuai dengan kondisi yang sudah dijelaskan di atas yaitu dana sosial yang bersumber dari wakaf khususnya wakaf uang merupakan skema yang layak. Hal ini memungkinkan karena potensi wakaf sangat besar dan pengumpulan wakaf bisa mulai dari nilai yang kecil misalnya Rp 500,-. Tetapi pengumpulannya memerlukan sistem dan media yang efisien dan mudah bagi para pewakafnya (wakif). Alternatif pemecahan masalah pengumpulan wakaf tersebut adalah dengan memanfaatkan teknologi informasi khususnya fasilitas internet dengan membuat e-wakaf atau Financial Technology (FinTech). E-wakaf atau FinTech sangat membantu siapapun untuk berwakaf dengan lebih mudah, lebih terintegrasi, dan lebih tertib administrasi serta berwakaf uang juga dapat dengan nominal yang kecil. Digitalisasi wakaf sangat penting karena potensi wakaf uang sangat besar dan lebih mudah diintegrasikan dengan sistem permodalan bagi para startup bisnis. 
Observasi dan wawancara terhadap pakar wakaf maupun pakar finansial teknologi serta FGD dengan para pemuda pelaku bisnis startup dihasilkan dua pokok pemikiran utama. Pertama, model wakaf sebagai solusi permodalan perusahaan startup yang dikelola oleh para pemuda. Kedua, model teknologi finansial syariah sebagai integrator solusi permodalan perusahaan startup yang berbasis wakaf.

Model Wakaf sebagai Solusi Permodalan Perusahaan Startup Para Pemuda

Model wakaf sebagai solusi permodalan perusahaan startup yang dikelolah para pemuda adalah seperti pada Gambar 1. Wakaf yang dapat digunakan untuk pemberdayaan dan atau sumber modal bagi perusahan startup adalah uang dan aset tidak bergerak atau aset yang dapat digunakan sebagai faktor produksi. Aset (uang dan non-uang) wakaf diserahkan kepada lembaga atau perorangan atau organisasi (nadzir) untuk dikelola agar memberikan manfaat kepada masyarakat dan aset tersebut tetap dijaga keberadaannya secara berkelanjutan.

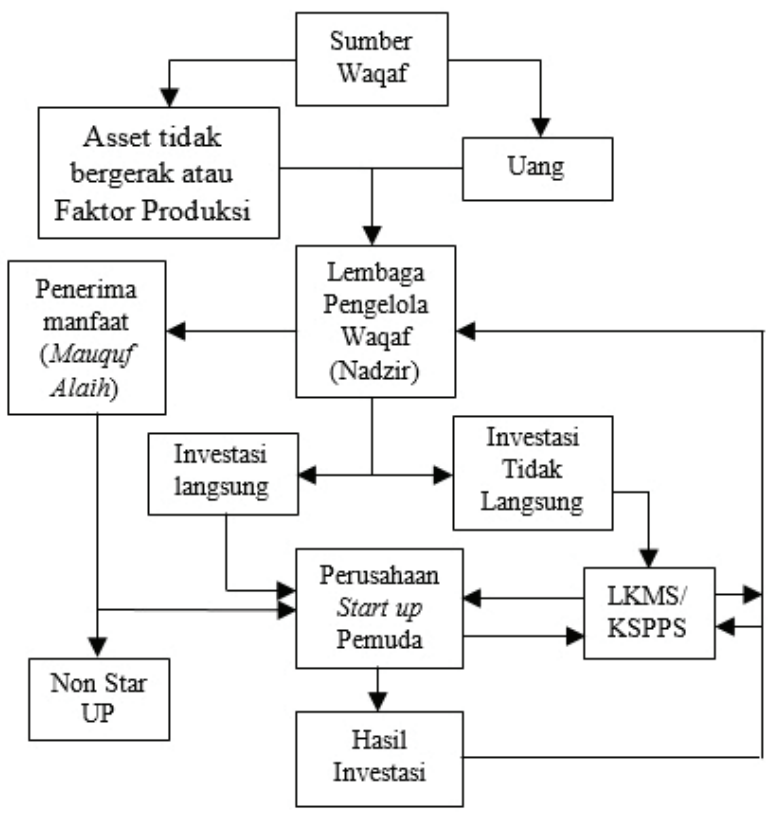

Gambar 1

Model Waqaf sebagai Solusi Permodalan Perusahaan Start up

Sumber: Formulasi hasil penelitian

Nadzir dalam mengelola aset wakaf yang tidak bergerak (tanah, gedung, mesin, dan faktor produksi lainnya) dapat langsung disertakan secara langsung dalam perusahaan startup. Faktor produksi ini langsung dapat digunakan oleh para perusahaan startup dalam produksi sebagai penyertaan. Aset wakaf yang dijadikan penyertaan harus dinilai secara rupiah, karena akan digunakan untuk memperhitungkan hak imbal hasil dari yang diperoleh dalam bisnis perusahaan startup.

Wakaf uang dalam pengelolaannya tidak boleh langsung dari nadzir kepada perusahaan startup, melainkan harus bekerjasama dengan lembaga keuangan atau manajer investasi. Bahkan wakaf uang hanya boleh diwakafkan melalui Lembaga Keuangan Syariah Penerima Wakaf Uang (LKS PWU) yang disahkan dan ditunjuk oleh Menteri Agama Republik Indonesia. Hal ini diatur dalam Peraturan Pemerintah Republik Indonesia Nomor 42 Tahun 2006 Tentang Pelaksanaan Undang-Undang Nomor 41 Tahun 2004 Tentang Wakaf, pada Pasal 23; "Wakif dapat mewakafkan benda bergerak berupa uang melalui LKS yang ditunjuk oleh Menteri sebagai LKS Penerima Wakaf Uang (LKS-PWU)". LKS PWU tersebut adalah Bank Umum Syariah (BUS), Unit Usaha Syariah (UUS), Lembaga Keuangan MIkro Syariah (LKMS), Koperasi Simpan Pinjam dan Pembiayaan Syariah (KSPPS), Unit Simpan Pinjam, dan Pembiayaan Syariah (USPPS). KSPPS ini di masyarakat lebih dikenal Baitul Maal Wat Tamwil (BMT).

Wakaf uang dalam kasus permodalan perusahaan startup ini dalam pengelolaannya bekerjasama dengan KSPPS atau USPPS yang telah menjadi nadzir dengan dua model. Model pertama, wakaf uang digunakan sebagai penyertaan modal pada perusahaan startup atau digunakan sebagai modal KSPPS atau USPPS yang akan disalurkan sebagai pembiayaan kepada para perusahaan startup. Model kedua, wakaf uang ditempatkan dalam KSPPS atau USPPS dengan akad mudharabah muqayadah. Akad mudharabah muaqayadah adalah akad mudharabah yang memberikan ketentuan syarat tertentu kepada pengelola dana (mudharib) dalam menyalurkan investasinya sesuai yang ditentukan oleh pemilik dana (shahibul maal). Pada kasus ini syarat utamanya hanya boleh disalurkan kepada para startup yang telah ditunjuk oleh shahibul maal.

Wakaf uang yang jadi penyertaan (modal) dalam bisnis perusaahaan startup harus dijaga keberadaannya dan apabila memperoleh hasil maka hasil tersebut dibagi antara startup dengan KSPPS atau 
USPPS sesuai dengan nisbah atau rasio yang telah disepakati pada saat akad ditandatangani. Bagi hasil yang diterima oleh KSPPS atau USPPS kemudian dibagi dengan nadzir berdasarkan nisbah atau rasio yang telah disepakatinya.

Hasil yang diterima oleh nadzir kemudian didistribusikan kepada penerima manfaat wakaf (mauquf alaih). Mauquf alaih ini juga boleh para perusahaan startup yang belum mampu atau dalam mengalami kesulitan dana bisnisnya serta perusahaan yang non-startup.

Model Sharia Financial Technology (SFT) Sebagai Integrator Solusi Permodalan Perusahaan Startup Pemuda Berbasis Wakaf

Financial Technology (FinTech) merupakan keniscayaan dalam industri keuangan sebagai konsekuensi dari era industri 4.0. Era industri 4.0 mengharuskan kegiatan produksi dan pelayanan terintegrasi melalui kecerdasan buatan, teknologi wireless, dan big data secara masif. Pada era industri ini merupakan era internet of thing dan data of thing yang menjadi penggerak perubahan dalam setiap aktivitas kehidupan manusia sehingga bisa dikatakan semua serba digital. Revolusi ini direspon oleh industri keuangan dengan lahirnya FinTech sebagai subtitusi dari pelayanan industri perbankan. Bahkan, dalam perkembangannya, FinTech mampu memberikan layanan melebihi kemampuan perbankan selama ini.

FinTech telah menggantikan fungsi perbankan dalam memediasi antara yang penawaran dana (penabung) dan permintaan dana (kredit) dengan ebih efisien tanpa batas waktu dan menembus batas wilayah yang selama ini sulit dijangkau perbankan. Sistem ini mampu mengintegrasikan dan mempertemukan pihak-pihak yang terlibat dalam jasa keuangan tanpa harus bertatap muka dan bertemu secara fisik tetapi dengan data lebih akurat daripada yang selama ini berlaku. Internet yang semakin cepat dan maju membuat data-data yang diperlukan dalam proses intermediasi keuangan dapat diperoleh dengan mudah, cepat, akurat, efisien, kapanpun, dan di manapun. Pada era ini fungsi teller, marketing, mitigasi risiko dan fungsi-fungsi perbankan lainya telah digantikan oleh smartphone yang selalu dibawa oleh setiap orang dan bisa dioperasikan kapan saja tanpa batas waktu dan tempat.

FinTech telah banyak diadopsi oleh industri keuangan konvensional maupun keuangan syariah. Digitalisasi ini juga mulai diadopsi oleh kegiatan filantropi dalam crowdfunding dan financing dengan menyasar dana kecil yang selama ini tidak efisien dirubah menjadi lebih efisien bahkan sangat efisien. Sistem FinTech ini juga mulai diadopsi oleh aktivitas perwakafan menjadi e-wakaf.

Aplikasi FinTech dalam perwakafan sebagai sumber permodalan perusahaan startup dapat dilihat pada Gambar 2.

Gambar 2

Model Sharia Financial Technology (SFT): Integrator dan Solusi Permodalan Perusahaan Start up Pemuda Berbasis Wakaf

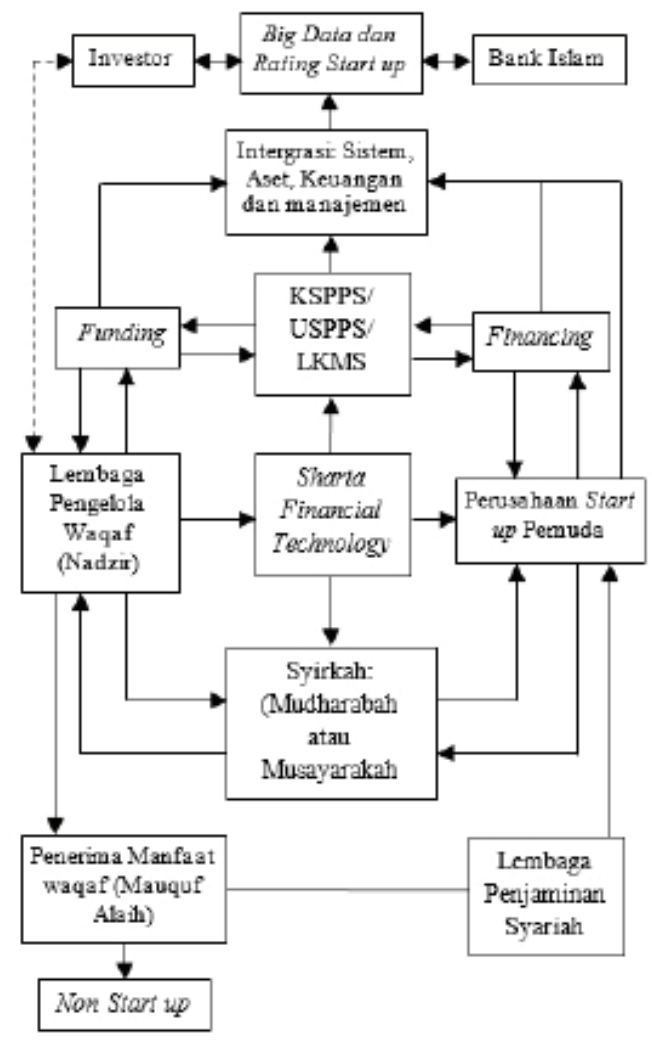

Sumber: Formulasi Hasil Penelitian

Pada Gambar 2, terlihat bahwa FinTech syariah yang diaplikasikan dalam sistem wakaf telah mampu mengintegrasikan nadzir dengan Lembaga Keuangan Syariah Penerima Wakaf Uang (LKSPWU), funding, financing, mauquf alaih, investor perusahaan startup, Lembaga Penjaminan Pembiayaan Islam (LPPI) dan Bank Islam. Model integrasi 
perwakafan dengan FinTech dapat digunakan untuk memecahkan permasalahan permodalan pada perusahaan startup. Pada sistem ini, lembaga pengelola wakaf uang (nadzir) memerankan fungsi ganda yaitu sebagai funding dan pemodal (penyertaan modal). Lembaga Keuangan Mikro Syariah (LKMS) dalam hal ini diperankan oleh Koperasi Simpan Pinjam dan Pembiayaan Syariah (KSPPS) dan/atau Unir Simpan Pinjam dan Pembiayaan Syariah (USPPS). Pengumpulan wakaf uang yang dilakukan oleh nadzir dengan menggunakan FinTech. Melalui sistem ini nadzir mampu mengumpulkan wakaf uang mulai dari nilai yang kecil sampai jumlah yang sangat besar sekalipun yang selama ini sangat tidak ekonomis menjadi sangat ekonomis karena biaya crowdfunding sangat murah bahkan bisa gratis. Hal ini tidak mungkin dilakukan tanpa dengan sistem FinTech. Pemproduktivitasan wakaf uang dengan FinTech dapat dilakukan baik secara langsung maupun tidak langsung.

Penyaluran wakaf uang secara langsung kepada perusahaan startup dengan investasi melalui akad mudharabah dan musyarakah. Pada kerjasama melalui akad mudharabah, pihak perusahaan startup bertindak sebagai pihak yang memiliki keahlian bisnis (mudharib). Sedangan pihak nadzir sebagai penyedia semua modal (shahibul maal) yang dibutuhkan pengusaha startup. Melalui akad musyarakah maka nadzir dan perusahaan startup sama-sama menyetorkan modal dengan nominal sesuai dengan kemampuan atau berdasarkan kesepakatan pihakpihak dalam musyarakah tersebut.

Penyaluran wakaf secara tidak langsung, yaitu nadzir menyalurkan wakaf melalui kerjasama dengan KSPPS dan USPPS. Kemudian melakukan financing kepada perusahaan startup dengan akad-akad yang sesuai dengan syariah. Pada sistem ini dana yang ditempatkan dalam KSSPS dan atau USPPS dapat dengan akad mudharabah muqayadah yang disalurkan khusus kepada perusahaan startup atau menjadi penyertaan modal dengan simpanan khusus.

Penyaluran wakaf sebagai permodalan perusahaan startup dengan syarat yang tidak rigid seperti syarat perbankan. Pertimbangan utama dalam permodalan ini keuntungan bagi perusahaan startup dan kepentingan masyarakat secara umum, komitmen dan business plan yang SMART (Specific, Measurable, Accurate, Reliable, and Timely). Hal ini karena tujuan utama dari sistem ini adalah memberi solusi sulitnya permodalan perusahaan startup dalam mengakses modal kepada lembaga keuangan formal yang orientasinya keuntungan.

Imbal hasil financing yang diberikan oleh perusahaan startup kepada lembaga baik secara langsung maupun tidak langsung dibagikan berdasarkan nilai tambah yang dihasilkan atau laba yang diperoleh. Sistem bagi hasil ini tidak muncul biaya tetap seperti pada sistem bunga sehingga tidak membebani perusahaan startup yang memang secara operasional belum stabil pendapatannya. Pembeda dalam bagi hasil pada sistem penyaluran langsung dengan penyaluran tidak langsung yaitu apabila penyaluran langsung bagi hasil terjadi satu tingkat saja. Satu tingkat bagi hasil tersebut yaitu bagi hasil antara perusahaan startup dengan nadzir. Sedangkan bagi hasil dalam sistem penyaluran tidak langsung dilakukan dengan dua tingkat. Tingkat pertama adalah bagi hasil antara perusahaan startup dengan KSPPS dan atau USPPS. Bagi hasil tingat kedua adalah bagi hasil dari imbal hasil yang diterima oleh KSPPS dan USPPS kemudian dibagi hasilkan lagi dengan nadzir.

Pendapatan bagi hasil yang diterima oleh nadzir akan digunakan untuk biaya operasional dan sisanya akan distribusikan kepada penerima manfaat wakaf (mauquf alaih). Mauquf alaih ini boleh perusahaan startup yang mengalami kesulitan bisnis baik secara langsung maupun tidak langsung. Perusahaan startup sebagai mauquf alaih secara tidak langsung adalah dengan cara dana tersebut digunakan untuk membayar fee penjaminan pada Lembaga Penjaminan Pembiayaan Islam (LPPI) pada saat pembiayaannya dari KSPPS dan atau USPPS membutuhkan jaminan. Mauquf alaih non-perusahaan startup yaitu untuk kepentingan umum dan pemberdayaan masyarakat.

FinTech yang diaplikasikan dalam model kasus penelitian ini juga akan mengintergrasikan sistem aset, administrasi keuangan, dan manajemen dari perusahaan startup, nadzir, mauquf alaih, KSPPS, USPPS dan LPPI. Integrasi ini akan membentuk 
big data dan dengan mudah melakukan rating bagi pihak-pihak yang terlibat dalam model ini. Big data dan rating akan semakin memudahkan perusahaan startup untuk mandiri. Perusahaan startup yang mandiri nantinya akan dilepas agar bermitra dengan Bank Islam, Lembaga Permodalan Islam lainnya dan investor individu maupun institusional. Apabila startup yang sudah mandiri ini tetap menggunakan modal dari wakaf maka harus menggunakan akad bisnis murni bukan dengan model filantropi lagi. Pada tahap selanjutnya, para startup yang telah mandiri tersebut harus menjadi wakif agar dana wakaf semakin tumbuh dan berkembang sehingga semakin banyak startup yang diberdayakan oleh lembaga wakaf. Siklus ini terus berputar sehingga fungsi wakaf dalam memberdayakan masyarakat dan menciptakan kemaslahatan umum semakin optimum dari waktu ke waktu.

\section{KESIMPULAN}

Perusahaan startup adalah perusahaan rintisan yang sedang mencari model bisnis yang repeatable serta scalable agar bisa bertahan. Persoalan dominan perusahaan startup adalah sulitnya akses permodalan pada perbankan. Wakaf uang merupakan solusi yang ekonomis dari permasalahan sulitnya akses permodalan bagi perusahaan startup pada perbankan.

Sistem Sharia Financial Technology (SF'T) merupakan sistem yang mampu mengintegrasikan nadzir dengan Lembaga Keuangan Syariah Penerima Wakaf Uang (LKSPWU), funding, financing, mauquf alaih, investor perusahaan startup, Lembaga Penjaminan Pembiayaan Islam (LPPI) dan Bank Islam. Manfaat lain aplikasi Fin'Tech ini adalah integrasinya sistem aset, administrasi keuangan, dan manajemen dari perusahaan startup, nadzir, mauquf alaih, KSPPS, USPPS dan LPPI. Selain itu dapat membentuk big data sehingga lebih mudah melakukan rating kinerja pihak-pihak yang terlibat dalam sistem. Dengan kata lain FinTech wakaf merupakan integrator para pihak yang berkepentingan memberikan solusi permasalahan permodalan dan pemberdayaaan perusahaan startup.

\section{DAFTAR PUSTAKA}

Afdi, Zihramna dan Purwanggono, Bambang. 2017. "Perancangan Strategi Berbasis Metodologi Lean Startup untuk Mendorong Pertumbuhan Perusahaan Rintisan Berbasis Teknologi di Indonesia". Industrial Enginerering Online Journal UNDIP Vol. 6 No. 4.

Agustina, Tri Siwi. 2011. "Peran Inkubator Bisnis

Perguruan Tinggi dalam Meminimalkan Resiko Kegagalan bagi Wirausaha Baru pada Tahap Awal (Start-Up)". Majalah Ekonomi Tahun XXI, No. 1 April 2011.

Amelia, Fauzia. 2016. FilantropiIslam: Sejarah dan Kontestasi Masyarkat Sipil dan Negara di Indonesia. Yogyakarta: Gading LkiS.

Bakar, Ridzwan. 2018. "Cash Waqf for education: Prospects and challenges." Journal of Emerging Economies and Islamic Research (2018) Vol. 6, No. 2

Blank, S., 2013. "Why The Lean Start-Up Changes Everything". Harvard Business Review. Diakses pada September 2018 (https://hbr. org/2013/05/why-the-lean-start-up-changeseverything)

Colis, D., 2016. Lean Strategy. Harvard Business Review. Diakses pada September 2018 (https://hbr.org/2016/03/lean-strategy).

Damodaran, Aswath. 2009. Valuing Young, Startup and Growth Companies: Estimation Issues and Valuation Challenges. Stern School of Business: New York University.

Hasanah, Lak Lak Nazhar El, 2015. "Pengembangan Wirausaha Muda Ekonomi Kreatif Berbasis Budaya di Daerah Istimewa Yogyakarta." Jurnal Studi Pemuda, Volume, 4, No., 2, September 2015.

John Watson dan Jim Everett, 1996, "Apakah Bisnis Kecil Memiliki Tingkat Kegagalan yang Tinggi?" Journal of Small Business Manajemen, V34, pg 45-63.

Kajian Bisnis Fin'Tech Syariah - P'T. Telkom Indonesia (Bandung: 2017), 56. 
Knaup, Amy E. dan MC. Piazza.September 2007. "Data Dinamika Ketenagakerjaan Bisnis: Survival dan Longevity" Monthly Labour Review, pp 3-10.

Nasscom, 2014. "India -The Fastest Growing and 3rd Largest Start-Up Ecosystem Globally: NASSCOM Startup Report 2014". Accessed September 2018 (http://www.nasscom.in).

Peraturan Bank Indonesia nomor 19/12/PBI/2017 tentang Penyelenggaraan Teknologi Finansial.

Peraturan Pemerintah Republik Indonesia Nomor 42 Tahun 2006 Tentang Pelaksanaan Undang-Undang Nomor 41 Tahun 2004 Tentang Wakaf.

Romanova, I., \& Kudinska, M. 2016. Contemporary

Issues in Finance: Banking and FinTech: A Challenge or Opportunity? London: Emerald Group Publishing Limited.

Schoof, Ulrich.2016. Stimulating Youth Entrepre neurship: Barriers and incentives to enterprise start-ups by young people. Geneva: Small Enterprise Development Programme Job Creation and Enterprise Development Department, International Labour Office.
Sifa, Eka Nurhalimatus. 2016. E-Waqf as an Alternative Solution for Infrastructure Development Based on Crowdfunding. Muhammadiyah University of Metro: The First International Conference on Law, Economics and Education.

Siregar, 2016. "Financial Technology Tren Bisnis Keuangan ke Depan". Diakses pada 1 April 2018 di (http://infobanknews.com).

Sutopo, Oki Rahadianto, dan Nanda Harda Pratama Meiji. “Transisi Pemuda Dalam Masyarakat Risioko: Antara Aspirasim Hambatan dan Ketidakpastian." Jurnal Universitas Paramadina Vol. 11 No. 3 Desember 2014.

Syarkawi, m. 2018. Republika.co.id, 27 September 2018.

Undang-Undang Republik Indonesia no. 41 Tahun 2014 tentang Wakaf.

Undang-Undang Republik Indonesia No. 40 Tahun 2009 tentang Kepemudaan. 